Фармацевтичний менеджмент, маркетинг та логістика

Pharmaceutical management, marketing and logistics

Рекомендована д. форамац. наук, проф. В. В. Трохимчуком

УДК 615.38:339.138(477)

DOI

\title{
ДОСЛІДЖЕННЯ ІНФУЗІЙНИХ РОЗЧИНІВ НА УКРАЇНСЬКОМУ ФАРМАЦЕВТИЧНОМУ РИНКУ
}

\author{
() О. Б. Калушка, А. В. Соколовська, Т. А. Грошовий \\ Тернопільський державний медичний університет імені І. Я. Горбачевського
}

\begin{abstract}
Резюме: здійснено дослідження асортименту інфузійних розчинів на фрармацевтичному ринку України. Наведено порівняння зареєстрованих інфузійних розчинів. Проаналізовано позиції України та іноземних країн - виробників щодо обсягу інфузійних розчинів на вітчизняному фрармацевтичному ринку.
\end{abstract}

Ключові слова: інфузійні розчини, інфузійна терапія, плазмозамінники, кровозамінники, парентеральне живлення, перитонеальний діаліз.

Вступ. Інфузійна терапія - це розділ медичної науки про управління срункціями організму шляхом цілеспрямованого впливу на морфологічний склад та фрізіологічні властивості крові. Еволюція фрармацевтичної технології щодо створення інфрузійних розчинів пройшла шлях від виготовлення їх в умовах аптеки до серійного виготовлення в умовах спеціалізованих фрармацевтичних підприємств. Раціональна інфузійна терапія $€$ однією з основ успішного лікування більшості внутрішніх захворювань. Інфузійна терапія змінила методи лікування багатьох нозологій, включно 3 дерматологічними та психічними захворюваннями [1, $2,3]$. Сучасна інфрузійна терапія являє собою потужний засіб лікування багатьох пацієнтів, у яких спостерігається втрата або патологічна зміна важливих, а інколи і життєво необхідних фрункцій організму. Серед досягнень інфузійної терапії в Україні слід зазначити постійне активне введення в клінічну практику нових інфузійних засобів [4, 5].

Станом на 1991 р. в Україні фрункціонувало 6500 аптек, серед них - 266 лікарняних і 250 - міжлікарняних. Однак підвищені вимоги до виготовлення стерильних лікарських форм та відсутність лікарських субстанцій практично звели нанівець екстемпоральне виготовлення в умовах аптеки. В Тернопільській області лише аптека № 126 має ліцензію на вигототовлення інфузійних розчинів.

Зазначимо, що у більшості закордонних країн при госпіталях фрункціонують виробничі аптеки. Їх функціонування виправдане насамперед на випадок надзвичайних ситуацій. Оскільки лише при внутрішньовенному введені препарату його біосумісність дорівнює $100 \%$, також даний спосіб введення дозволяє використовувати дози, що точно відповідають потрібному результату та звести до мінімуму індивідуальні відмінності у реакції на лікарський препарат [7, 8, 9].

За оцінкою Всесвітньої організації охорони здоров'я у світі щорічно виконується 8 - 12 млрд ін'єкцій, 3 них близько 1 млрд - дітям під час вакцинації. Встановлено, що в середньому одній людині виконують від 0,9 до 8,5 ін'єкцій на рік (в середньому - 1,5) [10]. Відомо, що на одного жителя країни повинен бути запас 1 л інфрузійних розчинів.

До позитивних моментів в розвитку фрармацевтичної галузі країни слід віднести появу нових підприємств-виробників інфузійних розчинів. Створені нові фрармацевтичні підприємства з виробництва інфузійних розчинів, однак номенклатура інфузійних розчинів порівняно із зарубіжними залишається обмеженою. Особливо це гостро проявилось в умовах надзвичайних станів, пов'язаних з наданням медичної допомоги.

Методи дослідження. Дослідження Державного реєстру інфузійних розчинів, використані методи інфрормаційного пошуку, узагальнення та аналізу.

Результати й обговорення. Станом на 01.02.2015 року, в Україні було зареєстровано 219 торгових назв інсузійних розчинів з врахуванням фрорм випуску [6].

Аналіз даних реєстрації інфрузійних розчинів показав, що найбільшу питому вагу в структурі торгових назв лікарських засобів для інфузійної терапії мають розчини, що містять електроліти та препарати гідроксиетильованного крохмалю (табл. 1).

На даний час на фрармацевтичному ринку України присутні інфузійні розчини 31 виробників, з них вітчизняних заводів - 16, що становить $52 \%$ ринку інфузійних розчинів та іноземних 15, що становить $48 \%$.

Вітчизняні заводи виготовляють менше половини від загальної кількості найменувань, це зумовлено тим, що велика кількість вітчизняних заводів випускає одні і ті ж найменування інфузійних розчинів. Українські заводи виготовляють, як правило, прості одноабо двокомпонентні розчини. Найбільш популярними серед вітчизняних виробників $є$ ізотонічний розчин натрію хлориду та препарат на основі декстрану реополіглюкін. Крім цього, на фрармацевтичному ринку

ISSN 2312-0967. Фармацевтичний часопис. 2015. № 4 
Фармацевтичний менеджмент, маркетинг та логістика Pharmaceutical management, marketing and logistics

Таблиця 1. Аналіз даних реєстрації інфузійних розчинів (станом на 1 лютого 2015 року)

\begin{tabular}{|c|c|c|c|}
\hline \multirow[t]{2}{*}{ АТС-код } & \multirow[t]{2}{*}{ Фармакологічна підгрупа } & $\begin{array}{c}\text { Кількість } \\
\text { зареєстрованих } \\
\text { торгових назв }\end{array}$ & Питома вага, \% \\
\hline & & \multicolumn{2}{|c|}{ без урахування фрорм випуску } \\
\hline \multicolumn{4}{|c|}{ В05А А Плазмозамінні та білкові фрракції плазми крові } \\
\hline Б05АA02 & Альбуміни & 5 & 3,96 \\
\hline B05AA05 & Декстрани & 4 & 4,21 \\
\hline B05AA06 & Препарати желатину & 2 & 3,17 \\
\hline B05AA07 & Препарати гідроксиетильованого крохмалю & 16 & 12,69 \\
\hline B05AA09 & Препарати повідону & 4 & 4,21 \\
\hline \multicolumn{4}{|c|}{ В05В А Розчини для парентерального живлення } \\
\hline B05BA01 & Амінокислоти & 9 & 7,14 \\
\hline B05BA02 & Жирові емульсії & 3 & 2,38 \\
\hline B05BA03 & Вуглеводи & 14 & 11,11 \\
\hline B05BA10 & Комбіновані препарати & 14 & 11,11 \\
\hline \multicolumn{4}{|c|}{ В05В В Розчини для корекції порушень електролітного балансу } \\
\hline B05BB01 & Електроліти & 21 & 16,66 \\
\hline B05BB02 & Електроліти з вуглеводами & 6 & 4,76 \\
\hline \multicolumn{4}{|c|}{ B05D Розчини для перитонеальногодіалізу } \\
\hline B05DBA & Розчини для перитонеальногодіалізу & 3 & 2,38 \\
\hline \multicolumn{4}{|c|}{ В05X А Розчини електролітів } \\
\hline B05XA01 & Калію хлорид & 2 & 3,17 \\
\hline B05XA02 & Натрію бікарбонат & 3 & 2,38 \\
\hline B05XA03 & Натрію хлорид & 16 & 12,69 \\
\hline B05XA31 & Електроліти у комбінації з іншими препаратами & 4 & 4,21 \\
\hline
\end{tabular}

досить широко представлені вітчизняні препарати полівінілпіролідону, однак повністю відсутні фрторвуглецеві кровозамінники та препарати желатину [11].
Лідером за кількостю виробників інфузійних розчинів на вітчизняному фрармацевтичному ринку $€$ Україна (рис. 1).

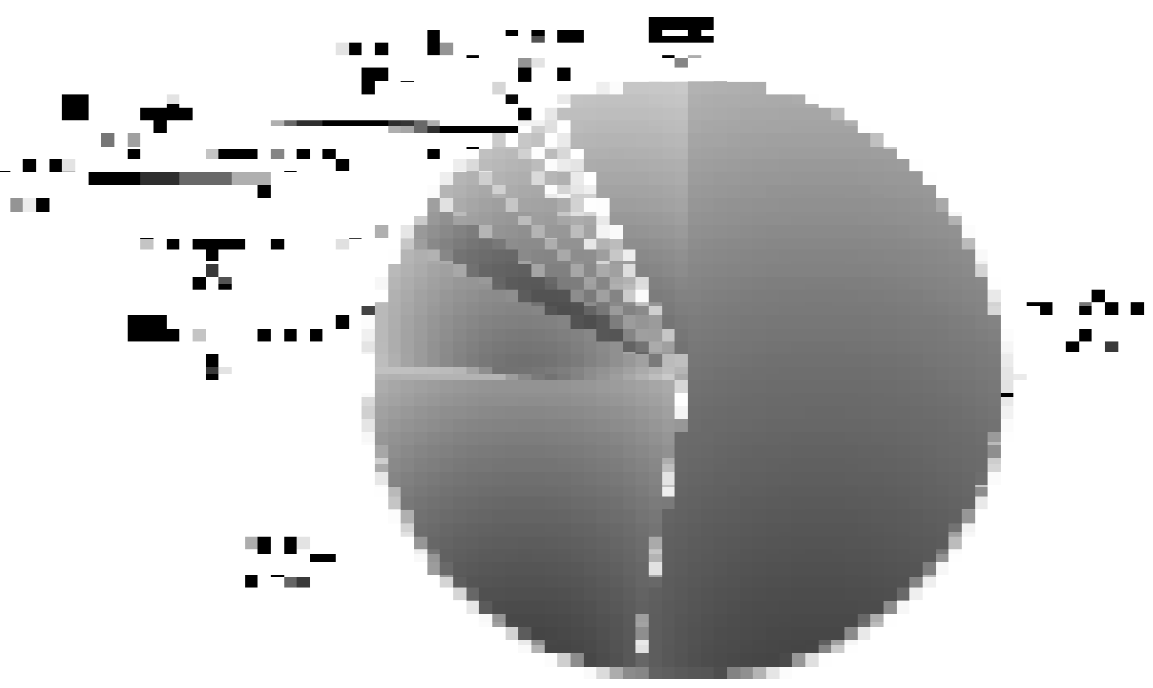

Рис. 1. Країни-виробники інфрузійних розчинів, представлені на українському фрармацевтичному ринку.

ISSN 2312-0967. Pharmaceutical review. 2015. № 4 
Серед вітчизняних виробників перші позиції із виробництва інфрузійних розчинів займають підприємства: ЗАТ«Юрія-Фарм», «Інфрузія», ТОВ фрірма «Новофрарм - Біосинтез» (рис. 2).

ЗАТ«Юрія-Фарм» виготовляє 31 торгове найменування, «Інфузія» - 22, ТОВ фрірма «Новофрарм - Біосинтез» - 13 (рис. 3).

Проведено розподіл зареєстрованих препаратів для парентерального живлення за фрірмами - виробниками по кількості торгових назв (рис. 3).

На українському фармацевтичному ринку наявний широкий спектр країн-виробників інфрузійних розчинів [12]. Майже половину асортименту іноземних інфузійних розчинів займають розчини виробництва Індії, також значну частину становлять розчини ви- робництва Німеччини. Крім цього, на ринку представлені інфузійні розчини виробництва: Австрії, Сербії, Швейцарії, Болгарії, Іспанії та Словенії (рис. 4).

Перші позиції за кількістю зареєстрованих інсрузійних розчинів іноземного виробництва займає виробник «Алкон Парентералз» (Індія) та «Євролайф Хелткеар Пвт. Лтд»(Індія) (рис. 5).

Для деталізації фрармацевтичного ринку проаналізовано такі групи інфузійних розчинів: дезінтоксикаційні, плазмозамінні, розчини для парантерального живлення та розчини електролітів.

Лідером за кількостю торгових назв плазмозамінних та дезінтоксикаційних розчинів $€$ Німеччина (виробник Berlin Chemie) - 5 торгових найменувань (рис. 6).

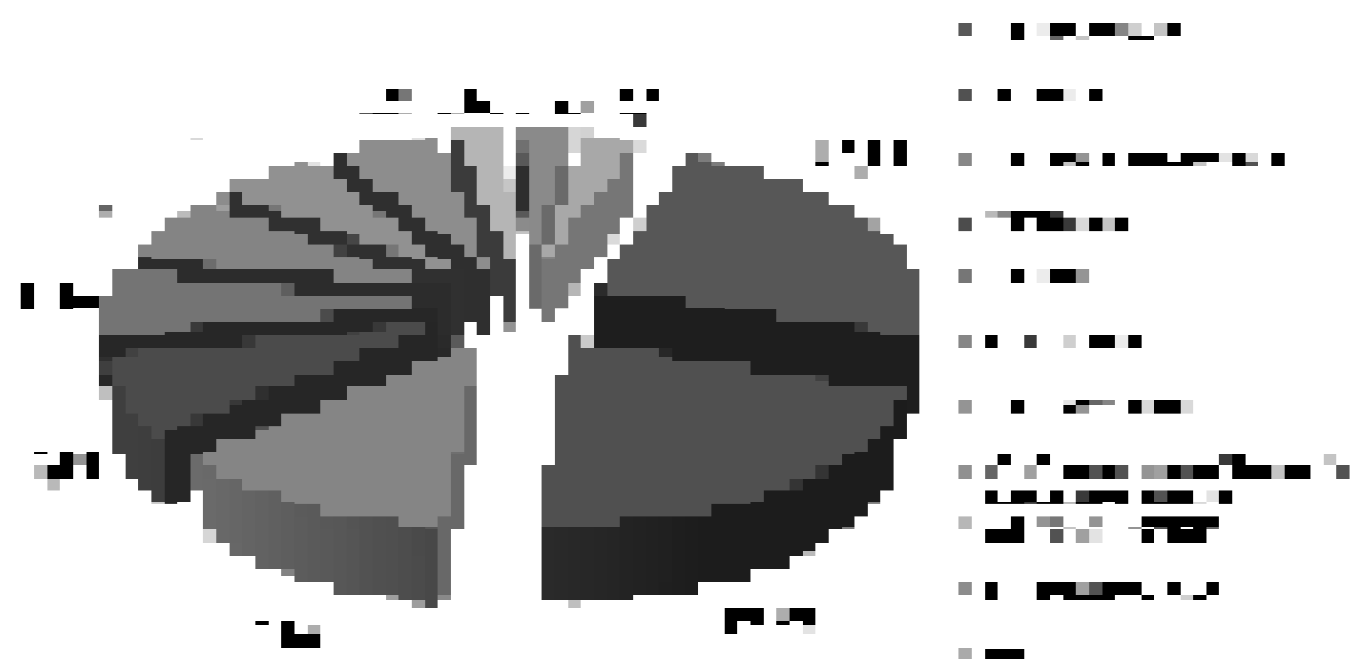

Рис. 2. Вітчизняні виробники інфрузійних розчинів на фрармацевтичному ринку України.
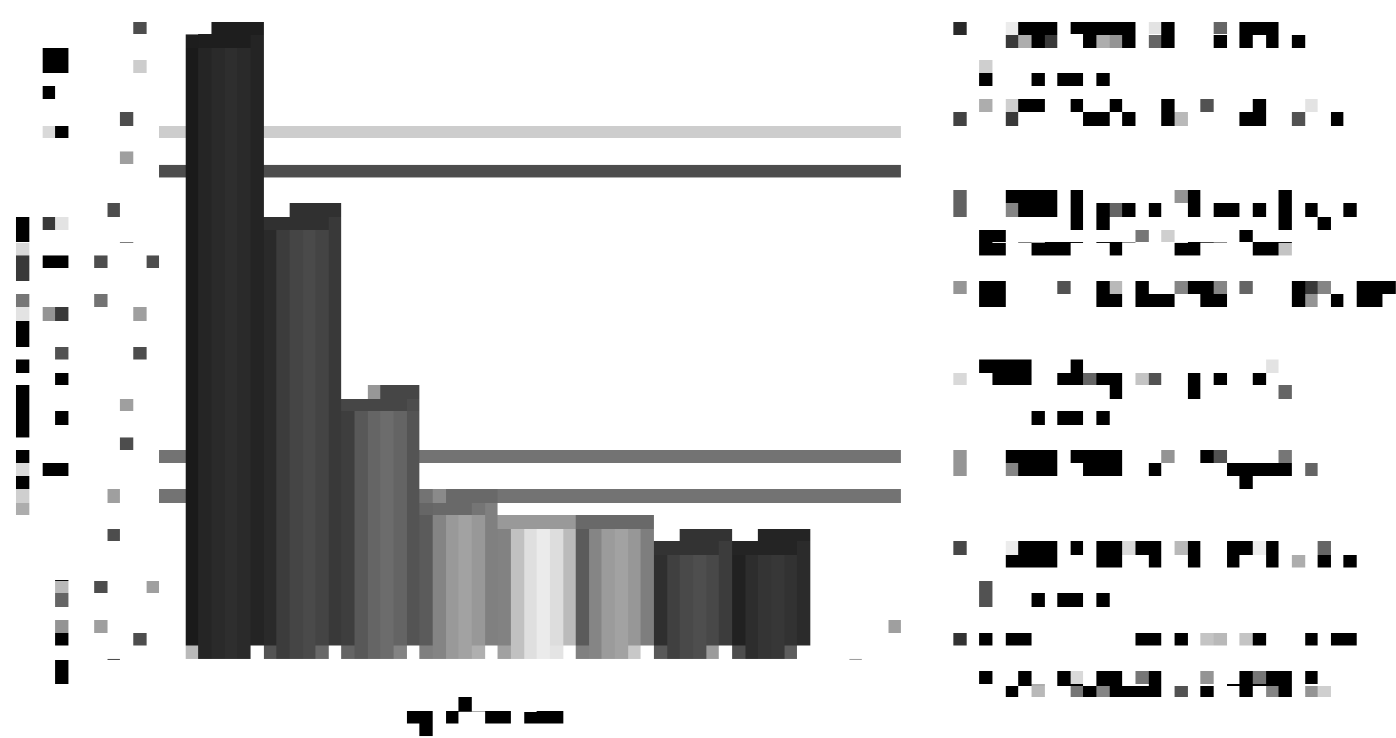

Рис. 3. Кількісний вираз торгових найменувань вітчизняних виробників інфузійних розчинів на фрармацевтичному ринку України.

ISSN 2312-0967. Фармацевтичний часопис. 2015. № 4 
Фармацевтичний менеджмент, маркетинг та логістика

Pharmaceutical management, marketing and logistics

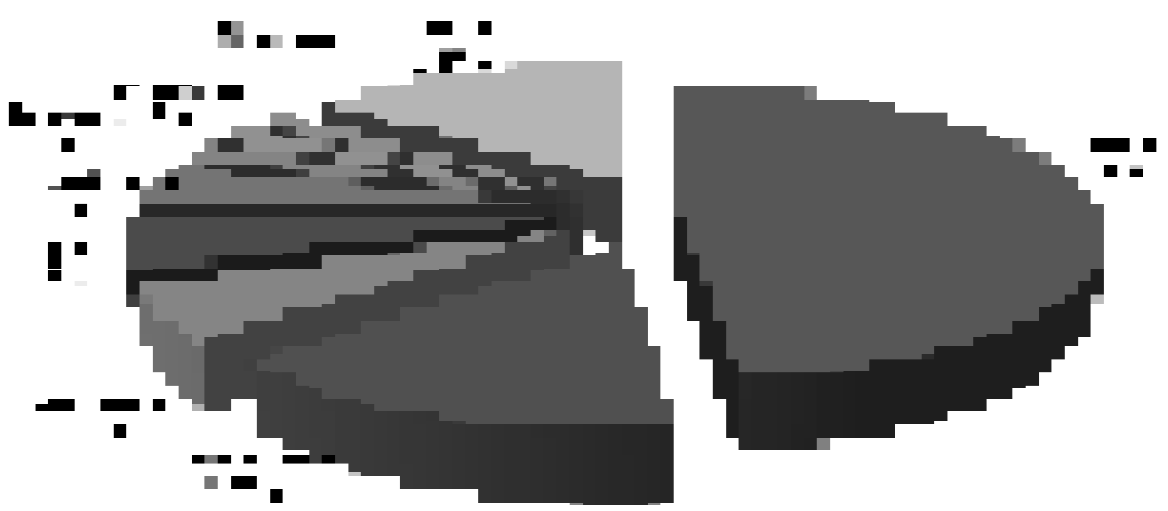

Рис. 4. Іноземні країни-виробники інсузійних розчинів, представлені на українському фрармацевтичному ринку.

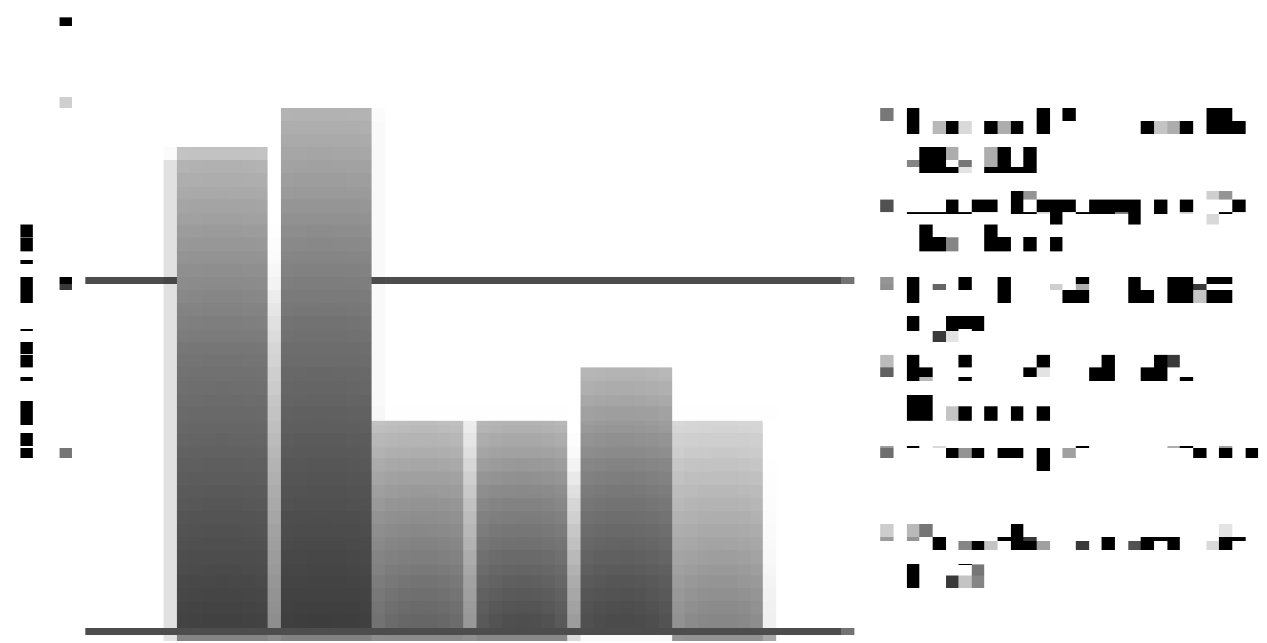

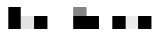

Рис. 5. Розподіл зареєстрованих інфузійних розчинів за виробниками.

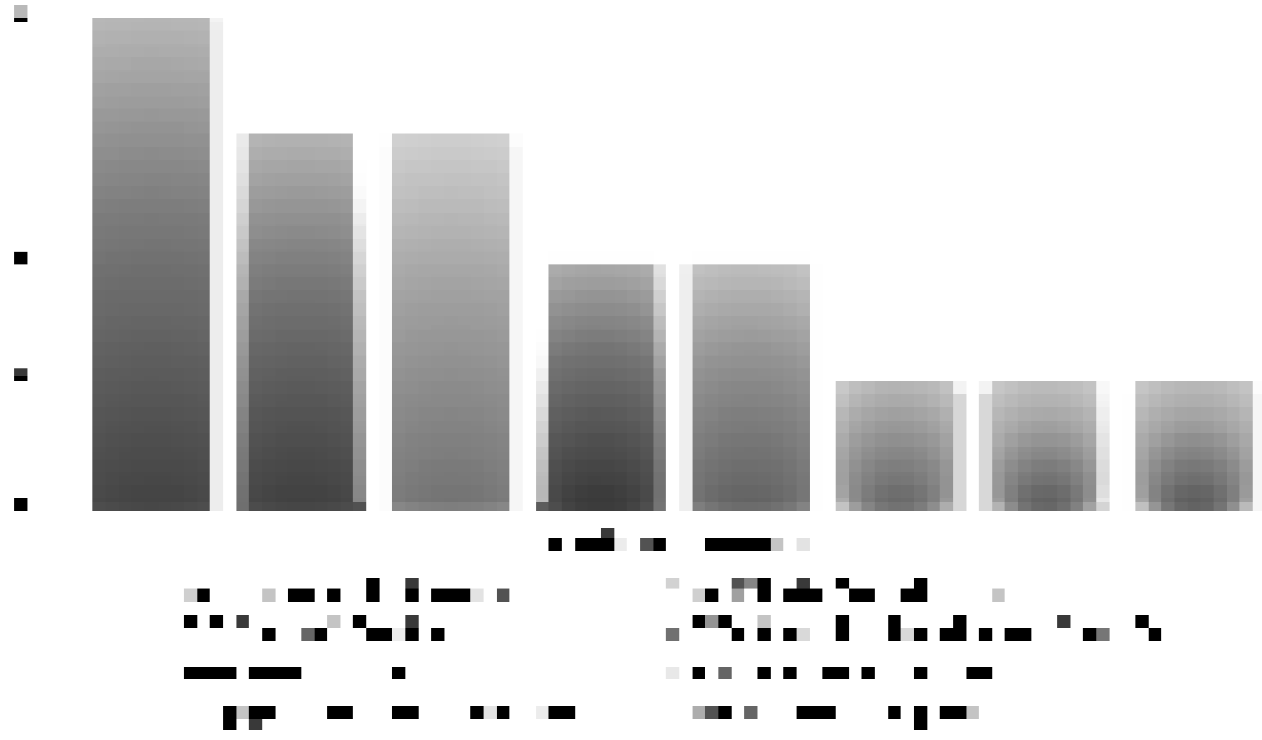

Рис. 6. Розподіл зареєстрованих плазмозамінних та деінтоксикаційних розчинів за виробниками. 
Фармацевтичний менеджмент, маркетинг та логістика Pharmaceutical management, marketing and logistics

Розчини для парентерального живлення. Найбільш широко вітчизняними виробниками представлені розчини вуглеводів, зокрема глюкози, що повністю забезпечує потреби фрармацевтичного ринку. Комбіновані розчини для парентерального живлення представлені іноземними виробниками. Вітчизняний виробник практично не виготовляє розчини жирових емульсій та розчини комбінованих препаратів, що містять у своєму складі амінокислоти та вуглеводи. На світовому ринку налічується значна кількість препаратів для парентерального живлення та перитонеального діалізу, це дозволяє здійснювати індивідуальний підхід до кожного пацієнта. На фрармацевтичному ринку України недо- статньо даних препаратів, особливо вітчизняного виробництва.

Розподіл зареєстрованих розчинів для парентерального живлення на фрармацевтичному ринку України показав, що лідером за кількістю торгових назв $є$ Німеччина - 9 торгових назв, також розчини виробництва Австрії становлять 5 торгових назв (рис. 7).

Інфузійнірозчини електролітів. Лідером за кількістю торгових назв зареєстрованих розчинів електролітів $є$ Німеччина (виробник Berlin Chemie) - 5 торгових назв. Провідними серед українських виробників $\epsilon$ ЗАТ "Інфузія" та ТОВ "Юрія-Фарм", які виготовляють по чотири найменування (рис. 8).

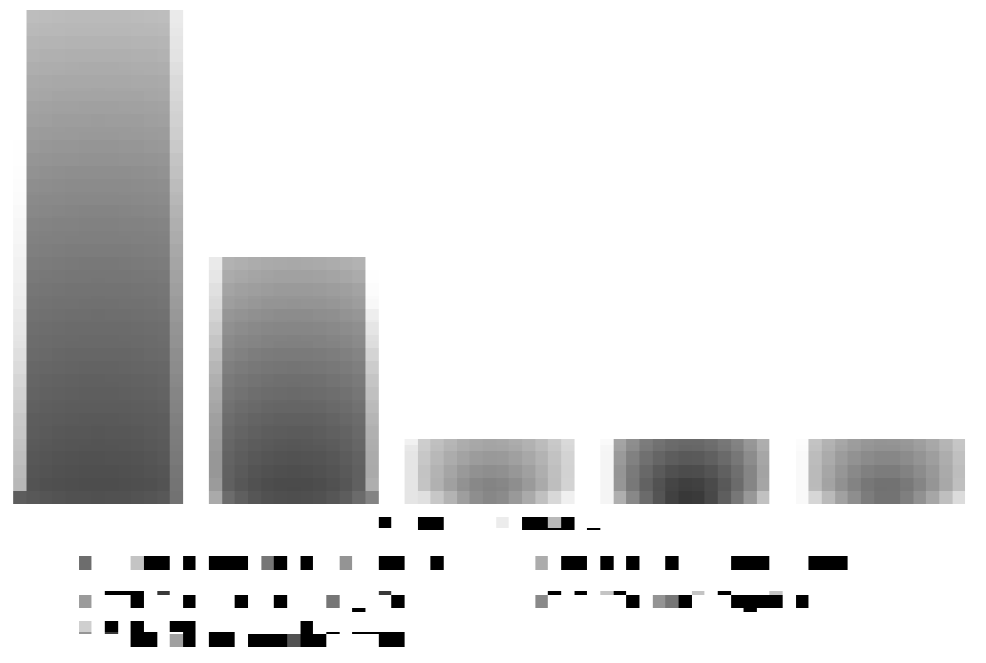

Рис. 7. Розподіл зареєстрованих розчинів для парентерального живлення за виробниками

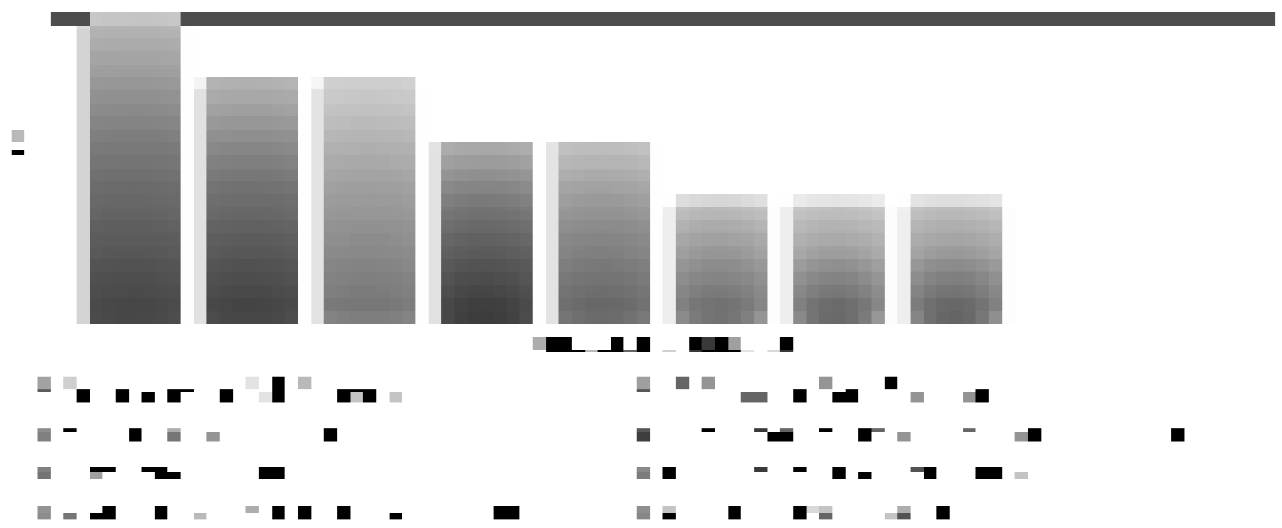

Рис. 8. Розподіл зареєстрованих розчинів-електролітів за виробниками.

Висновки. Аналіз асортименту інфузійних розчинів за виробниками свідчить, що вітчизняні виробники постачають на фармацевтичний ринок України переважно препарати, що містять невелику кількість неорганічних іонів або їх комбінації з вуглеводами.
Забезпечення різних категорій хворих життєво важливими інфузійними розчинами як препарати для парентерального живлення амінокислотного та ліпідного складу та розчинами для перитонеального діалізу залежить від іноземних виробників. На фрармацевтич-

ISSN 2312-0967. Фармацевтичний часопис. 2015. № 4 
Фармацевтичний менеджмент, маркетинг та логістика

Pharmaceutical management, marketing and logistics

ному ринку лідером за кількістю виробників інфрузійних розчинів є Україна. Серед вітчизняних виробників перші позиції із виробництва інфузійних розчинів займають підприємства ЗАТ«Юрія-Фарм», «Інфрузія» та ТОВ фрірма «Новофрарм - Біосинтез». Ассортимент іноземних інфузійних розчинів на українському фрар- мацевичному ринку складають розчини виробництва Індії, також значну частину становлять розчини виробництва Німеччини. Перші позиції із кількості зареєстрованих інфузійних розчинів іноземного виробництва посідає виробник «Алкон Парентералз» (Індія) та «Євролайор Хелткеар Пвт. Лтд»(Індія).

\section{Список літератури}

1. Гудзь Н. І. Застосування розчинів для перитонеального діалізу у медичній практиці / Н. І. Гудзь // Клінічна фрармація. - 2006. - № 2. - С. 19-23.

2. Інсрузійні лікарські засоби улікуванні політравм/Я. Л. Заруцький, О. П. Шматенко, А. М. Соломенний [та ін.] // Український хіміотерапевтичний журнал. - 2012. - № 3 (27). - С. 31-36.

3. Фещенко Ю. І. Інфузійна терапія в клініці внутрішніх хвороб / Ю. І. Фещенко, Н.І.Гуменюк // Український хімікотерапевтичний журнал - 2008. - № 1-2(22). - С. 9.

4. Шлапак І. П. Інфрузійна терапія в практиці лікаря внутрішньої медицини / І. П. Шлапак, В. 3. Нетяженко, О. А. Галушко. - Київ, 2013. - 216 с.

5. Фещенко Ю. І. Інфузійна терапія в клініці внутрішніх хвороб / Ю. І. Фещенко, Н.І.Гуменюк: [Електронний pecypc] /: http://uf.ua/lib/395/

6. Державний реєстр лікарських засобів:[Електронний pecypc] /:http://www.drlz.kiev.ual

7. Нетяженко В. 3. Неінтенсивна інфузійна терапія в практиці лікаря внутрішньої медицини / В. 3. Нетяженко, О. А. Галушко // Укр. хіміотерапевтич. журнал. - 2012. -
№ 3(26). - С. 164-169.

8. Руденко В. В. Розробка науково обґрунтованої технології полііонних ентеральних лікарських засобів: автореф. дис. на здобуття наук. ступеня канд. фрармац. наук : спец. 15.00.01 / В. В. Руденко. - Київ, 2001. - 18 с. 9. Гудзь Н. І. Розробка складу і науково обґрунтованої технології енергополііонних та колоїдних розчинів для парентерального застосування : авторефр. дис. на здобуття наук. ступеня канд. фрармац. наук : спец. 15.00.01 / Н. І. Гудзь. - Київ, 2002. - 23 с.

10. Гудзь Н. І. Історичні аспекти застосування інсузійних розчинів / Н. І. Гудзь, Р. С. Коритнюк, Т. А. Борисенко // Несумісні та нераціональні сполучення лікарських засобів для парентерального застосування. - Київ, 2012. - С. 12.

11. Яковлева О. С. Маркетингове дослідження вітчизняного ринку лікарських засобів для інсрузійної терапії / О. С. Яковлева // Соціальна фрармація: стан, проблеми та перспективи. - 2014. - С. 251.

12. Компендіум : [Електронний pecypc]/:http:// compendium.com.ua

\title{
МАРКЕТИНГОВОЕ ИССЛЕДОВАНИЕ ИНФУЗИОННЫХ РАСТВОРОВ НА УКРАИНСКОМ ФАРМАЦЕВТИЧЕСКОМ РЫНКЕ
}

\author{
Е. Б. Калушка, А. В. Соколовская, Т. А. Грошовый \\ Тернопольский государственный медицинский университет имени И. Я. Горбачевского
}

Резюме: в статье выполнено исследование ассортимента инсузионных растворов на фрармацевтическом рынке Украины. Приведено сравнение зарегистрированных инсузионных растворов. Проанализировано позиции Украины та иностранных стран-производителей относительно размеров произведения инфузионных растворов на отечествном рынке.

Ключевые слова: инфузионные растворы, инфузионная терапия, плазмозаменители, заменители крови, парентеральное питание, перитонеальный диализ.

\section{MARKETING RESEARCH OF INFUSION SOLUTIONS AT UKRAINIAN PHARMACEUTICAL MARKET}

\section{O. B. Kalushka, A. V. Sokolovska, T. A. Hroshovyi \\ Ternopil State Medical University by I. Ya. Horbachevsky}

Summary: the article presents the results of the research on the range of infusion solutions at the pharmaceutical market of Ukraine. The comparison of the registered infusion solutions is presented. In the paper the position of Ukraine and foreign countries as producers as to the amount of the infusion solutions at Ukrainian pharmaceutical market is analyzed.

Key words: infusion solutions, infusion therapy, plasma substitutes, blood substitutes, parenteral nutrition, peritoneal dialysis. 